Sains Malaysiana 50(2)(2021): 475-480

http://dx.doi.org/10.17576/jsm-2021-5002-18

\title{
Association between Prothrombin Induced by Vitamin K Absence-II (PIVKA- II) and Barcelona Clinic Liver Cancer (BCLC) Stage, Tumor Size, Portal Venous Thrombosis in Hepatocellular Carcinoma Patients
}

(Perkaitan antara Protrombin yang Dipengaruhi oleh Ketiadaan Vitamin K II (PIVKA-II) dan Tahap Kanser Hati Klinik Barcelona (BCLC), Saiz Tumor, Trombosis Vena Portal pada Pesakit Karsinoma Hepatosel)

\author{
DARMADI DARMADI* \& RISKA HABRIEL RUSLIE
}

\begin{abstract}
Hepatocellular carcinoma is one of the major cancer problems in the world because of the low early screening awareness in patients. Serum alpha-fetoprotein is not adequate as a single screening tool, especially for small HCCs, thus, prothrombin induced by vitamin K absence-II (PIVKA-II) can help in detecting small HCCs. Barcelona Clinic Liver Cancer $(B C L C)$ stage remains to be the preferred HCC classification because it can predict the outcome and help in choosing available treatment options according to stages. This study aims to investigate the association between PIVKA-II levels with BCLC stage, tumor size, portal venous thrombosis in HCC patients. We enrolled patients with newly diagnosed HCC at the Adam Malik General Hospital, Medan, Indonesia from January to December 2018. Patients with HCC were classified according to BCLC stages, findings of portal venous thrombosis and tumor size from triphasic CT scan were noted, and serum PIVKA-II levels were measured. Sixty patients were included in this study. There were significant differences in serum PIVKA-II levels with different stages of BCLC $(p<0.001)$. Significantly higher serum PIVKA-II levels were detected in patients with portal venous thrombosis $(p<0.001)$ and larger size tumors $(p<0.003)$. Our study shows that serum PIVKA-II levels can help to diagnose, differentiate between stages of BCLC, and determine the prognosis in patients with HCC.
\end{abstract}

Keywords: Hepatocellular carcinoma; hepatoma; liver cell carcinoma; tumor biomarkers

\section{ABSTRAK}

Karsinoma hepatosel adalah salah satu masalah kanser utama di dunia kerana kesedaran awal yang rendah dalam kalangan pesakit. Serum alfa-fetoprotein tidak mencukupi sebagai alat pemeriksaan tunggal, terutamanya untuk HCCs kecil, oleh itu protrombin yang disebabkan oleh ketiadaan vitamin K II (PIVKA-II) dapat membantu dalam mengesan HCCs kecil. Tahap Kanser Hati Klinik Barcelona (BCLC) tetap menjadi pilihan dalam pengelasan HCC kerana dapat meramalkan hasil dan membantu dalam memilih pilihan rawatan yang tersedia mengikut tahap. Kajian ini bertujuan untuk mengkaji hubungan antara tahap PIVKA-II dengan peringkat BCLC, saiz tumor, trombosis vena portal pada pesakit HCC. Kami mendaftarkan pesakit dengan HCC yang baru didiagnosis di Hospital Besar Adam Malik, Medan, Indonesia sepanjang tempoh Januari hingga Disember 2018. Pesakit dengan HCC dikelaskan mengikut tahap BCLC, penemuan trombosis vena portal dan saiz tumor daripada imbasan CT triphasic dicatat dan paras serum PIVKA-II dihitung. Enam puluh pesakit dimasukkan ke dalam kajian ini. Terdapat perbezaan yang signifikan antara paras serum PIVKA-II dengan peringkat BCLC yang berlainan $(p<0.001)$. Tahap serum PIVKA-II yang lebih tinggi dikesan pada pesakit dengan trombosis vena portal $(p<0.001)$ dan tumor saiz yang lebih besar $(p<0.003)$. Kajian kami menunjukkan bahawa tahap serum PIVKA-II boleh membantu untuk mendiagnosis, membezakan antara peringkat BCLC dan menentukan prognosis pada pesakit dengan HCC.

Kata kunci: Hepatoma; karsinoma hepatosel; karsinoma sel hati; penanda biologi tumor

\section{INTRODUCTION}

Hepatocellular carcinoma (HCC) is one of the major cancer problems in the world (Tang et al. 2018). Usually asymptomatic in the early stage, it causes high mortality because of the low awareness in early screening from the patient (He et al. 2013). Challenges in clinical practice diagnosis of HCC often precludes early treatment, thus, reducing the survival rate (Pazgan-Simon et al. 2015). Some serum biomarkers are introduced to detect HCC at early 
stages, such as alpha-fetoprotein (AFP) and prothrombin induced by vitamin $\mathrm{K}$ absence-II (PIVKA-II), also known as des- $\gamma$-carboxyl prothrombin (DCP) (Chen et al. 2018).

Serum AFP, which has been widely used for the screening of HCC, is not an adequate single screening tool, especially for small HCCs (Carr et al. 2018), thus, it is important to find new non-AFP markers for early diagnosis. Prothrombin induced by vitamin K absence-II (PIVKA-II), also known as des- $\gamma$-carboxyl prothrombin (DCP) has been linked to HCC especially in the early stages compared with non-HCC, especially hepatitis B virus (HBV) related HCC (Wang et al. 2017). It is released in the absence of vitamin $\mathrm{K}$ or when its action is antagonized by vitamin $\mathrm{K}$ antagonists (warfarin) (Zhang et al. 2014). In patients with $\mathrm{HCC}$, there is impairment of vitamin $\mathrm{K}$ uptake which causes the production of PIVKA-II, aggravated by unfavorable microenvironments such as hypoxia (Murata et al. 2010).

Over the years, some methods have been developed to classify the severity of HCC, but Barcelona Clinic Liver Cancer (BCLC) staging remains to be preferred because it can predict the outcome and help in planning treatment options depending on the stages (Saraswat et al. 2014). However, BCLC staging itself is not perfect, moreover in stage B (intermediate stage) which has a heterogeneous population with varying degree of severity, thus preventing determination of optimal treatment option and resulting in heterogeneity of prognosis (Bolondi et al. 2012; Farinati et al. 2015; Kinoshita et al. 2015).

Therefore, to help diagnose and further determine the best treatment option and prognosis for patients with HCC, this study aims to investigate the association between serum PIVKA-II levels with BCLC stage, tumor size, portal venous thrombosis in $\mathrm{HCC}$ patients.

\section{MATERIALS AND METHODS}

This cross-sectional study included a minimum of 54 patients with newly diagnosed HCC, all of which were presented at outpatients' clinic or emergency unit at the Adam Malik General Hospital, Medan, Indonesia from January to December 2018. The diagnosis of HCC was confirmed by a triphasic CT scan (arterial hypervascularity followed by venous and/or delayed phase 'washout') (Pang et al. 2019). Findings of portal venous thrombosis and tumor size were noted. The presence or absence of portal venous thrombosis was noted. Tumor size was classified into less than 3, 3 to 5 , and more than $5 \mathrm{~cm}$. Patients with cholangiocarcinoma, hemangioma, and liver metastasis were excluded from the study. Informed consent and approval from all patients were obtained after sufficient information was given about the study before enrollment. The study was approved by the Institutional
Review Board of Universitas Sumatera Utara No. 417/ TGL/KEPK FK USU-RSUP HAM/2017.

Patients with HCC were classified according to Barcelona Clinic Liver Cancer (BCLC) classification to early-stage HCC (stage A), intermediate stage HCC (stage B), advanced stage (stage C), and terminal stage (stage D) based on tumor extension, liver functional reserve, physical status, and cancer-related symptoms (Kinoshita et al. 2015). Three milliliters of blood samples were collected from antecubital vein following proper aseptic procedures into EDTA tube, then stored at two to eight degrees Celsius. All samples were centrifuged for $15 \mathrm{~min}$ to obtain serum then stored at minus twenty degrees Celsius before subjected to measure PIVKA-II level using PIVKAII kit (Stago Diagnostica, France) by ELISA technique (Zakhary et al. 2013).

Statistical analysis was performed using SPSS 22.0 software (IBM Corp., Armonk, NY, USA). The distribution of serum PIVKA-II levels was analyzed using the Kolmogorov-Smirnov test. A comparison of serum PIVKA-II levels between two groups was done using an independent sample t-test if the distribution of serum PIVKA-II levels was normal, Mann-Whitney U test was used otherwise. One-way ANOVA was used to compare the serum PIVKA-II levels between more than 2 groups if the distribution was normal, Kruskal-Wallis test was used if the distribution was not normal, then serial MannWhitney $\mathrm{U}$ tests were used for pair-wise comparison. P-value of $<0.05$ was considered significant.

\section{RESULTS AND DISCUSSION}

A total of 60 subjects were enrolled in this study. The mean age for subjects was 61.4 (SD 11.7) years. Male subjects were dominant $(78.3 \%)$. More than half of the subjects had Hepatitis B infection as the etiology of hepatocellular carcinoma. Based on BCLC staging, 25 (41.7\%) subjects were in stage C. Most subjects had portal venous thrombosis and tumors with a diameter of $>5 \mathrm{~cm}$. The median PIVKA-II level in this study was $149.5 \mathrm{ng} / \mathrm{mL}$. Subjects' characteristics distribution was shown in Table 1.

There were significant differences in serum PIVKA-II levels in patients with different stages of BCLC (Figure 1). Serum PIVKA-II levels were significantly higher ( $P$ $=0.002$ ) in patients with BCLC stage B compared with patients with BCLC stage A. Similar results were obtained when serum PIVKA-II levels of patients with BCLC stage A were compared with patients with BCLC stage $\mathrm{C}$ and $\mathrm{D}(\mathrm{P}<0.001$ and $\mathrm{P}<0.001$, respectively). There were also significant differences in serum PIVKA-II levels of patients with BCLC stage B compared with patients with BCLC stage $\mathrm{C}$ and $\mathrm{D}(\mathrm{P}=0.006$ and $\mathrm{P}=0.028$, respectively $)$. 
Serum PIVKA-II levels were not different between patients with BCLC stage $\mathrm{C}$ and $\mathrm{D}(\mathrm{P}=0.759)$.

Some of the prognostic factors of HCC (portal venous thrombosis and tumor size) were compared (Table 2) and significantly higher serum of PIVKA-II levels was detected in patients with portal venous thrombosis $(\mathrm{P}=$ $0.001)$ and larger size tumor $(\mathrm{P}=0.003)$. There were no significant differences when comparing tumor size less than 3 and $3-5 \mathrm{~cm}(\mathrm{P}=0.199)$.

TABLE 1. Characteristics of hepatocellular carcinoma patients

\begin{tabular}{|c|c|}
\hline Characteristic & $\mathrm{n}=60$ \\
\hline Mean age, years (SD) & $61.4(11.7)$ \\
\hline \multicolumn{2}{|l|}{ Sex, n (\%) } \\
\hline Male & $47(78.3)$ \\
\hline Female & $13(21.7)$ \\
\hline \multicolumn{2}{|l|}{ Etiology, n (\%) } \\
\hline Hepatitis B & $42(70.0)$ \\
\hline Hepatitis C & $5(8.3)$ \\
\hline Non-alcoholic fatty liver disease & $13(21.7)$ \\
\hline \multicolumn{2}{|l|}{ BCLC stages, n (\%) } \\
\hline Stage A & $5(8.3)$ \\
\hline Stage B & $21(35.0)$ \\
\hline Stage C & $25(41.7)$ \\
\hline Stage D & $9(15.0)$ \\
\hline \multicolumn{2}{|l|}{ Portal venous thrombosis, $\mathrm{n}(\%)$} \\
\hline Present & $33(55.0)$ \\
\hline Absent & $27(45.0)$ \\
\hline \multicolumn{2}{|l|}{ Tumor size, $\mathrm{n}(\%)$} \\
\hline$<3 \mathrm{~cm}$ & $8(13.3)$ \\
\hline $3-5 \mathrm{~cm}$ & $24(40.0)$ \\
\hline$>5 \mathrm{~cm}$ & $28(46.7)$ \\
\hline Median PIVKA-II levels, ng/mL (min-max) & $149.5(29-204)$ \\
\hline
\end{tabular}

TABLE 2. Serum prothrombin induced vitamin K absence-II (PIVKA-II) levels of hepatocellular carcinoma patients with different prognostic factors

\begin{tabular}{lcc}
\hline & PIVKA-II levels $(\mathrm{ng} / \mathrm{mL})$ & \\
\hline Portal venous thrombosis & $168(52-204)$ & \\
Present & $89(29-187)$ & $0.001^{\mathrm{a}}$ \\
Absent & $58(35-175)$ & \\
Tumor size & & $0.005^{\mathrm{b}}$ \\
$<3 \mathrm{~cm}$ & $135.5(29-200)$ & $0.006^{\mathrm{b}}$ \\
$3-5 \mathrm{~cm}$ & $176(79-204)$ & --- \\
\hline $5 \mathrm{~cm}$ & & \\
\hline
\end{tabular}

${ }^{\mathrm{a}}$ Mann-Whitney U test, ${ }^{\mathrm{b}} \mathrm{Mann}-$ Whitney U test, compared to tumor size $>5 \mathrm{~cm}$ 


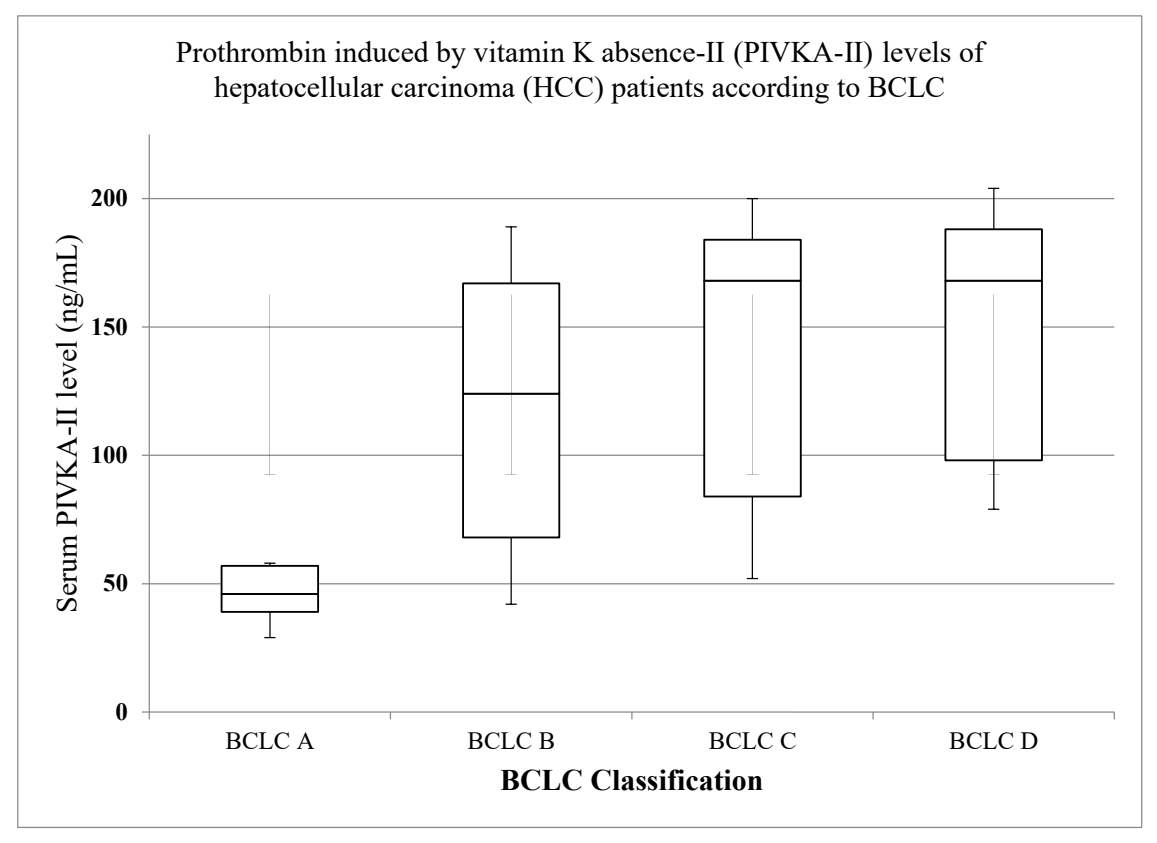

FIGURE 1. Prothrombin induced by vitamin K absence-II (PIVKA-II) levels of hepatocellular carcinoma (HCC) patients according to Barcelona Clinic Liver Cancer (BCLC) classification. *p-value $<0.05$

Liver cancer is one of the most common cancer and the leading cause of cancer death in the world (Tang et al. 2018). Liver cancer, especially HCC can be classified by using BCLC classification which is used to guide the treatment allocation for each stage of BCLC (Saraswat et al. 2014). The adherence to BCLC treatment allocation recommendation in clinical practice varies according to the stages, but it positively impacts the survival rate, moreover in patients with BCLC stage A (Kikuchi et al. 2017), thus HCC needs to be diagnosed early (Yu et al. 2016). In this study, the patients were treated according to their BCLC classification. Patients in stage A BCLC underwent liver resection in one patient, radiofrequency ablation in two patients, and the other two patients refused any kind of treatment modalities. All patients Stage B BCLC underwent trans-arterial chemoembolization (TACE), whereas all patients in stage C BCLC were treated with sorafenib. Best supportive care was chosen by all patients in stage D BCLC.

The results of the treatment and prognosis of the patients however are within the limitation of the current study.

This study showed that there was a higher male proportion of HCC patients. This finding is consistent with studies by Liu et al. (2017) and Wu et al. (2018), although a study by Zhang et al. (2019) stated the reduced male- to-female incidence rate ratio among persons aged less than 50 years old. Male predominance is more likely to be caused by hormonal differences between males and females, specifically premenopausal females (Keng et al. 2012; Li et al. 2017).

Compared with alpha-fetoprotein (AFP), it is known that PIVKA-II is superior in early diagnosis (Ma et al. 2018; Svobodova et al. 2018; Wu et al. 2018), because of the gradual increase in serum PIVKA-II levels according to stages and the severity of HCC (Yu et al. 2017; Zakhary et al. 2013). This is consistent with the result of this study which showed higher serum PIVKA-II levels in patients with portal venous thrombosis, tumor size more than 5 $\mathrm{cm}$, and higher stages of BCLC but not between stage $\mathrm{C}$ and stage D BCLC. Increasing serum PIVKA-II levels were associated with progression and oncogenesis of HCC (Yu et al. 2017), whereas BCLC were used for predicting the prognosis of the patients, based not only on the severity of liver damage and tumor stage but also based on the performance status of the patients (Pons et al. 2005). This finding might show there was no difference in the progression of $\mathrm{HCC}$ in stage C compared to stage D BCLC, but there might be changes in the prognosis of the patient due to performance status.

This study showed that there were differences in serum PIVKA-II levels of patients with BCLC stage B 
compared with stage $\mathrm{C}$ and stage $\mathrm{D}$. According to BCLC treatment allocation, it is recommended to treat stage $\mathrm{B}$ BCLC with TACE (Marrero et al. 2018), however, a study by Farinati et al. (2015) stated that TACE could not be considered as the best treatment option for BCLC stage $\mathrm{B}$ in clinical practice. Another study by Zhaohui et al. (2018) concluded that patients with stage B1 according to Bolondi's subclassification (Bolondi et al. 2012) benefited from hepatic resection and had comparable survival rate with BCLC stage A patients. Studies by Kamiyama et al. $(2017,2015)$ showed that hepatectomy could be considered in BCLC stage B HCC patients with tumor number less than 4 and/or AP-factor $(\mathrm{AFP} \times$ PIVKAII) less than $1 \times 10^{5}$.

There were some limitations to our current study. We currently do not have follow-up data of the patients after treatment and currently have not subclassified BCLC stage B HCC according to Bolondi's subclassification because of limited patients in stage B. Further studies are needed to see whether serum PIVKA-II levels can help determine the best treatment option for heterogeneous patients, especially in BCLC stage B HCC patients according to Bolondi's subclassification.

\section{CONCLUSION}

Our study can conclude that serum PIVKA-II levels can help to diagnose, differentiate between stages of BCLC, and determine the prognostic factors (tumor size and presence of portal venous thrombosis) in patients with HCC.

\section{ACKNOWLEDGEMENTS}

The authors acknowledge the assistance of the Department of Pathology, Faculty of Medicine, Universitas Sumatera Utara, Indonesia.

\section{REFERENCES}

Bolondi, L., Burroughs, A., Dufour, J.F., Galle, P.R., Mazzaferro, V., Piscaglia, F., Raoul J.L. \& Sangro, B. 2012. Heterogeneity of patients with intermediate (BCLC B) hepatocellular carcinoma: Proposal for a subclassification to facilitate treatment decisions. Semin Liver Dis. 32(4): 348-359.

Carr, B.I., Akkiz, H., Üsküdar, O., Yalçın, K., Guerra, V., Kuran, S., Karaoğullarından, Ü., Altıntaş, E., Özakyol, A., Tokmak, S., Ball, T., Yücesoy, M., Bahçeci, H.İ., Ülkü, A., Akçam, T., Polat, K.Y., Ekinci, N., Şimşek, H., Örmeci, N., Sonsuz, A., Demir, M., Kılıç, M., Uygun, A., Demir, A., Delik, A., Arslan, B., Doran, F., Yilmaz, S. \& Tokat, Y. 2018. HCC with low- and normal-serum alpha-fetoprotein levels. Clin. Pract. (Lond) 15(1): 453-464.

Chen, H., Zhang, Y., Li, S., Li, N., Chen, Y., Zhang, B., Qu, C., Ding, H., Huang, J. \& Dai, M. 2018. Direct comparison of five serum biomarkers in early diagnosis of hepatocellular carcinoma. Cancer Manag. Res. 10: 1947-1958.

Farinati, F., Vanin, V., Giacomin, A., Pozzan, C., Cillo, U., Vitale, A, Di Nolfo, A.M., Del Poggio, P., Benvegnu', L., Rapaccini, G., Zoli, M., Borzio, F., Giannini E.G., Caturelli, E., Trevisani, F. \& Italian Liver Cancer (ITA.LI.CA) group. 2015. BCLC stage B hepatocellular carcinoma and transcatheter arterial chemoembolization: A 20 -year survey by the Italian Liver Cancer group. Liver Int. 35(1): 223-231.

He, W., Xu, M., Xu, R., Zhou, X., Ouyang, J., Han, H. \& Chen, G. 2013. Inpatients' knowledge about primary liver cancer and hepatitis. Asian Pac. J. Cancer Prev. 14(8): 4913-4918.

Kamiyama, T., Yokoo, H., Kakisaka, T., Orimo, T., Wakayama, K., Kamachi, H., Tsuruga, Y., Yamashita, K., Shimamura, T., Todo, S. \& Taketomi, A. 2015. Multiplication of alphafetoprotein and protein induced by vitamin $\mathrm{K}$ absence-II is a powerful predictor of prognosis and recurrence in hepatocellular carcinoma patients after a hepatectomy. Hepatol. Res. 45(10): E21-E31.

Kamiyama, T., Orimo, T., Wakayama, K., Shimada, S., Nagatsu, A., Yokoo, H., Kamachi, H., Yamashita, K., Shimamura, T. \& Taketomi, A. 2017. Survival outcomes of hepatectomy for stage B hepatocellular carcinoma in the BCLC classification. World J. Surg. Oncol. 15(1): 156.

Keng, V.W., Largaespada, D.A. \& Villanueva, A. 2012. Why men are at higher risk for hepatocellular carcinoma? J. Hepatol. 57(2): 453-454.

Kikuchi, L., Chagas, A.L., Alencar, R.S.S.M., Tani, C., Diniz, M.A., D'Albuquerque, L.A.C. \& Carrilho, F.J. 2017. Adherence to BCLC recommendations for the treatment of hepatocellular carcinoma: Impact on survival according to stage. Clinics (Sao Paulo) 72(8): 454-460.

Kinoshita, A., Onoda, H., Fushiya, N., Koike, K., Nishino, H. \& Tajiri, H. 2015. Staging systems for hepatocellular carcinoma: Current status and future perspectives. World $J$. Hepatol. 7(3): 406-424.

Liu, P., Xie, S.H., Hu, S., Cheng, X., Gao, T., Zhang, C. \& Song, Z. 2017. Age-specific sex difference in the incidence of hepatocellular carcinoma in the United States. Oncotarget 8(40): 68131-68137.

Li, Y., Li, H., Spitsbergen, J.M. \& Gong, Z. 2017. Males develop faster and more severe hepatocellular carcinoma than females in krasV12 transgenic zebrafish. Sci. Rep. 7(1): 41280.

Ma, X.L., Zhu, J., Wu, J., Tian, L., Gao, Y.Y., Zhang, C.Y., Zhou, Y. Dai, Q., Wang, B.L., Pan, B.S., Zhou, J., Fan, J., Yang, X.R. \& Guo, W. 2018. Significance of PIVKA-II levels for predicting microvascular invasion and tumor cell proliferation in Chinese patients with hepatitis B virus-associated hepatocellular carcinoma. Oncol. Lett. 15(6): 8396-8404.

Marrero, J.A., Kulik, L.M., Sirlin, C.B., Zhu, A.X., Finn, R.S., Abecassis, M.M., Roberts, L.R. \& Heimbach, J.K. 2018. Diagnosis, staging, and management of hepatocellular carcinoma: 2018 practice guidance by the American Association for the Study of Liver Diseases. Hepatology 68(2): 723-750.

Murata, K., Suzuki, H., Okano, H., Oyamada, T., Yasuda, Y. \& Sakamoto, A. 2010. Hypoxia-induced des- $\gamma$-carboxy 
prothrombin production in hepatocellular carcinoma. Int. $J$. Oncol. 36(1): 161-170.

Pang, G., Duan, Z., Shao, C., Zhao, F., Zhong, H. \& Shao, G. 2018. Heterogeneity analysis of triphasic CT scan perfusion parameters in differential diagnosis of hepatocellular carcinoma and hemangioma. Medicine (Baltimore) 97(38): e12512.

Pazgan-Simon, M., Serafinska, S., Janocha-Litwin, J., Simon, K. \& Zuwala-Jagiello, J. 2015. Diagnostic challenges in primary hepatocellular carcinoma: Case reports and review of the literature. Case Rep. Oncol. Med. 2015: 878763.

Saraswat, V.A., Pandey, G. \& Shetty, S. 2014. Treatment algorithms for managing hepatocellular carcinoma. J. Clin. Exp. Hepatol. 4(Suppl 3): 80-89.

Svobodova, S., Karlikova, M., Topolcan, O., Pecen, L., Pestova, M., Kott, O., Treska, V., Slouka, D. \& Kucera, R. 2018. PIVKA-II as a potential new biomarker for hepatocellular carcinoma - a pilot study. In Vivo 32(6): 1551-1554.

Tang, A., Hallouch, O., Chernyak, V., Kamaya, A. \& Sirlin, C.B. 2018. Epidemiology of hepatocellular carcinoma: Target population for surveillance and diagnosis. Abdom. Radiol. 43(1): 13-25.

Wang, X., Zhang, W., Liu, Y., Gong, W., Sun, P., Kong, X., Yang, M. \& Wang, Z. 2017. Diagnostic value of prothrombin induced by the absence of vitamin $\mathrm{K}$ or antagonist-II (PIVKAII) for early stage HBV related hepatocellular carcinoma. Infect Agents Cancer 12(1): 1-8.

Wu, E.M., Wong, L.L., Hernandez, B.Y., Ji, J.F., Jia W, Kwee, S.A. \& Kalathil, S. 2018. Gender differences in hepatocellular cancer: Disparities in nonalcoholic fatty liver disease/steatohepatitis and liver transplantation. Hepatoma Res. 4(10): 66.

Wu, J., Xiang, Z., Bai, L., He, L., Tan, L., Hu, M. \& Ren, Y. 2018. Diagnostic value of serum PIVKA-II levels for BCLC early hepatocellular carcinoma and correlation with HBV DNA. Cancer Biomark. 23(2): 235-242.

Yu, R., Xiang, X., Tan, Z., Zhou, Y., Wang, H. \& Deng, G. 2016. Efficacy of PIVKA-II in prediction and early detection of hepatocellular carcinoma: A nested case-control study in Chinese patients. Sci. Rep. 6(1): 1-12.
Yu, R., Tan, Z., Xiang, X., Dan, Y. \& Deng, G. 2017. Effectiveness of PIVKA-II in the detection of hepatocellular carcinoma based on real-world clinical data. BMC Cancer 17(1): 608.

Zakhary, N.I., Khodeer, S.M., Shafik, H.E. \& Abdel Malak, C.A. 2013. Impact of PIVKA-II in diagnosis of hepatocellular carcinoma. J. Adv. Res. 4(6): 539-546.

Zhang, X., El-Serag, H.B. \& Thrift, A.P. 2019. Sex and race disparities in the incidence of hepatocellular carcinoma in the United States examined through age-period-cohort analysis. Cancer Epidemiol Biomarkers Prev. 29(1): 88-94.

Zhang, Y., Chu, J., Cui, S., Song, Z. \& Qu, X. 2014. Des- $\gamma-$ carboxy prothrombin (DCP) as a potential autologous growth factor for the development of hepatocellular carcinoma. Cell Physiol. Biochem. 34(3): 903-915.

Zhaohui, Z., Shunli, S., Bin, C., Shaoqiang, L., Yunpeng, H., Ming, K., Lijian, L. \& Gang, P.B. 2018. Hepatic resection provides survival benefit for selected intermediate-stage (BCLC-B) hepatocellular carcinoma patients. Cancer Res. Treat. 51(1): 65-72.

Darmadi Darmadi*

Department of Internal Medicine

Faculty of Medicine

Universitas Sumatera Utara

Dr. Mansyur 5, Medan

Indonesia

Riska Habriel Ruslie

Faculty of Medicine

Universitas Prima Indonesia

Ayahanda 68 A, Medan

Indonesia

*Corresponding author; email: ign.darmadi@yahoo.com

Received: 5 April 2020

Accepted: 5 August 2020 